\title{
Self-stopping tomatoes - cultural and economic aspects*
}

\author{
A. J. de Visser ${ }^{1}$ and K. Buitelaar ${ }^{2}$
}

${ }^{1}$ Agricultural Economics Research Institute, The Hague, the Netherlands

2 Glasshouse Crops Research and Experiment Station, Naaldwijk, the Netherlands

\section{Introduction}

The present system of tomato growing, in which the crop is in the glasshouse for up to 10 months, is very labour-intensive. Side-shooting, twisting, leaf picking and harvesting are continually recurring operations. At the Institute for Plant Breeding at Wageningen, work is in progress to develop a crop type which requires little labour for cultural operations. To achieve this the plant must be made self-stopping with little or no lateral growth. The stems must be made sturdy enough to obviate the need for support. The plants must therefore remain low. For single harvesting the fruits should ripen simultaneously and, if this aim cannot be achieved entirely, the fruits, when ripe, should be retained on the plants in good condition for some time (Hogenboom, 1974). If these aims can be achieved, it should become possible to utilize the whole of the glasshouse area for the crop. A plant density of 10 plants per $\mathrm{m}^{2}$ would become feasible (Buitelaar, 1973). The cropping cycle would be 2 to 3 months, depending on the season, and four crops per year would be possible. Some experience has already been gained in cropping experiments with some prototypes of self-stopping tomatoes.

\section{Cultural aspects}

\section{Plant raising and planting}

Because of the high density of the crop it will be necessary to raise large numbers of plants. This will require a large propagation area and a great deal of labour. Planting out will also require a lot of labour for a short time and the obvious answer is to mechanize plant raising and planting out. If a smaller plant is required for mechanical planting, this would mean a longer cropping cycle and a higher crop cost.

\section{Cultural operations}

In the experiments it was always found necessary to support the crop. The use of chrysanthemum netting or canes requires more labour and makes harvesting difficult. The plants must therefore be made self-supporting which would also increase the possibilities of mechanization (Postel, 1967).

With the present prototypes it is necessary to side-shoot at least twice and to remove the lower leaves to avoid suffocation of the crop. In the self-stoppers of

* Publikatie van het Proefstation voor de Groenten- en Fruitteelt onder Glas te Naaldwijk No 205 . 
the future lateral growth must be limited and suffocation of the lower leaves must be prevented by the application of the right climatic conditions.

Fruit set in the present tomato crop has to be aided by various artificial means. Suitable methods may have to be found to achieve the same with self-stoppers grown at high densities in which fruit set will certainly not become any easier. The use of a high-pressure sprayer has already given good results.

\section{Harvest}

The harvesting period in the experiments lasted for 3 to 4 weeks. Single harvesting is of course the ideal, but the high labour requirements over a short period would make mechanisation necessary. The highest yield obtained in the experiments so far was $5 \mathrm{~kg}$ per $\mathrm{m}^{2}$. The yield was reduced by disease (botrytis) and by magnesium deficiency. The latter in particular is still a big problem, but it may well be possible to developed less susceptible varieties. There also appear to be good possibilities of increasing yields by improved growing methods.

\section{Technical equipment}

As a crop of self-stoppers will cover practically the whole of the ground area, the equipment will have to be adapted to this growing method. Overhead irrigation of the crop provides a favourable climate for all kinds of diseases (Vriesenga, 1972). The use of a low-level irrigation system beneath the crop would therefore be preferable. The heating pipes would also have to be accommodated beneath the crop as far as possible, as with other bed systems of growing, in order to obtain satisfactory heat distribution. If the heating pipes are installed in the path, they may also be used as rails for a transport system.

\section{Economic aspects}

\section{Introduction}

The most obvious feature of the cropping system described is the high plant requirement. For four crops a year this is 40 plants per $\mathrm{m}^{2}$ of glasshouse. For the normal two-crop system - a heated crop from mid-December until 1 July and an autumn crop from 5 July until 20 November -5 plants are required per $\mathrm{m}^{2}$. This large number of plants has consequences for plant raising in terms of space and labour requirements, as well as for planting out when a great deal of labour is required in a short time. With the figures known for plant requirements and labour, an assessment was made of the production costs of year-round cropping with selfstoppers.

There is, of course, also the question whether it would be economically justified to use self-stoppers in summer. In other words, will the gross returns expected be sufficient to cover the direct costs like the cost of the plant material, pesticides, fertilizers, transport costs and the labour costs for planting, harvesting, grading and supervision? With some other glasshouse crops which have relatively high plant costs, such as irises and pot chrysanthemums, the crops costs are often not covered in summer by the gross returns. From an economic point of view it is then more 
Table 1. Labour requirements for a crop of self-stopping tomatoes in minutes per $100 \mathrm{~kg}$ $(=100$ plants $)$.

\begin{tabular}{|c|c|c|}
\hline Operation & $\begin{array}{l}\text { With present } \\
\text { methods of } \\
\text { planting and } \\
\text { harvesting }\end{array}$ & $\begin{array}{l}\text { After mechanization } \\
\text { of planting and } \\
\text { harvesting }\end{array}$ \\
\hline Planting and watering in & 20 & 10 \\
\hline Harvesting & 50 & 20 \\
\hline Grading & 15 & 15 \\
\hline Packing & 3 & 3 \\
\hline Transport & 2 & 2 \\
\hline \multirow[t]{2}{*}{ Crop clearance } & 5 & 0 \\
\hline & 75 & 40 \\
\hline Supervision & 5 & 5 \\
\hline Total labour requirements per $100 \mathrm{~kg}$ & 100 & 55 \\
\hline Total labour requirements for $1000 \mathrm{~m}^{2}$ & 167 hours & 92 hours \\
\hline
\end{tabular}

attractive to grow a crop with a better cost/return relationship, such as lettuce, or to leave the glasshouse empty.

\section{The labour requirements}

In consultation with Ing. A. T. M. Hendrix ${ }^{1}$ an estimate was made of the labour requirements expected in self-stopping tomato crops. The calculations were based on the assumption that yields of $1 \mathrm{~kg}$ per plant would be obtained.

The labour requirements in minutes per 100 plants were assessed for two situations:

1. with the present methods for planting, harvesting and crop clearance;

2. after mechanization of planting, harvesting and crop clearance.

The labour saved by mechanized harvesting was estimated at 30 minutes per 100 $\mathrm{kg}$. It was also assumed that the harvesting machine clearing the crop gives a saving of another 5 minutes per $100 \mathrm{~kg}$. The cost of the harvesting machinery was estimated to be equal to two-thirds of the value of the labour saving. This means that at an hourly rate of $f$ (Dutch guilders) 12.40 (on 1 July 1974) the machine costs for harvesting and crop clearance would be

$$
2 / 3 \times 35 / 60 \times f 12.40=f 4.82 \text { per } 100 \mathrm{~kg} .
$$

The labour saving in planting was assessed at 10 minutes per $100 \mathrm{~kg}$, and here also it was assumed that the machine costs would be equal to two-thirds of the labour saving expected. This would give a machine cost for planting of:

$$
2 / 3 \times 10 / 60 \times f 12.40=f 1.38 \text { per } 100 \text { plants }(100 \mathrm{~kg}) .
$$

Table 1 shows that the labour requirements for four crops of self-stopping toma-

1 Labour specialist of the IMAG at Wageningen, stationed at the Glasshouse Crops Research and Experiment Station, Naaldwijk, the Netherlands. 
toes, with the present techniques, would be $4 \times 167=668$ hours $+10 \%$ for miscellaneous jobs $=735$ hours per $1000 \mathrm{~m}^{2}$. The normal-heated tomato crop with a yield of $15 \mathrm{~kg}$ per $\mathrm{m}^{2}$ and the autumn crop with a yield of $10 \mathrm{~kg}$ per $\mathrm{m}^{2}$ have a labour requirement of 820 hours per $1000 \mathrm{~m}^{2}$, including the allowance for miscellaneous jobs. Substitution of the normal crops with four self-stopping crops would produce a $10 \%$ reduction in total labour requirements. Labour productivity would be greatly improved and would be increased from $31 \mathrm{~kg}$ per labour hour with the normal two-crop system to $54 \mathrm{~kg}$ per labour hour with the four self-stopping crops with the present-day growing methods. After mechanization of harvesting and planting labour, productivity is further increased to $99 \mathrm{~kg}$ per labour hour.

Substantial labour savings are achieved by mechanization of planting and harvesting. Four mechanized self-stopping crops have a labour requirement of $4 \times$ $92=368$ hours $+10 \%$ miscellaneous jobs $=405$ hours per $1000 \mathrm{~m}^{2}$ compared with 735 hours with present growing techniques and 820 hours for the present twocrop system. Mechanization of planting and harvesting would give a $45 \%$ reduction in the labour requirements compared with the present growing techniques for self-stoppers and a reduction of $51 \%$ compared with the present two-crop system.

\section{Estimate of production costs}

\section{Basis for calculations}

The hourly rate for labour used in the calculations was $f 12.40$, the level on 1 July 1974. All operations were carried out by casual labour and the grower. The net cost of gas for heating was taken as $f 0.08$ per $\mathrm{m}^{3}$, the price level on 1 October 1974. The annual cost of fixed equipment, overheads and that portion of the grower's labour which could not be attributed directly to the crop, was assessed in all cases at $f 12$ per $\mathrm{m}^{2}$. These are the so-called fixed costs.

The normal cropping system was assumed to consist of a heated crop from midDecember until 1 July with a yield of $15 \mathrm{~kg}$ per $\mathrm{m}^{2}$, followed by an autumn crop from 5 July until 20 November with a yield of $10 \mathrm{~kg}$ per $\mathrm{m}^{2}$.

The harvest dates of the four self-stopping crops were presumed to be on 15 March, 31 May, 31 July and 15 October.

In apportioning the fixed costs, the net margins of the second, third and fourth crop were deducted from the fixed costs of the four crops. The remainder of the fixed cost was apportioned to the first crop in every case.

Table 2. Production costs of self-stopping tomato crops with four harvest dates and two different growing systems.

\begin{tabular}{llcccc}
\hline Growing system & \multicolumn{5}{c}{ Production costs in Dutch guilders per $\mathrm{m}^{2}$} \\
\cline { 2 - 6 } & $15 / 3$ & $31 / 5$ & $31 / 7$ & $15 / 10$ & total \\
Present methods & 22 & 11 & 7 & 8 & 48 \\
Mechanized method & 20.50 & 11 & 7 & 8 & 46.50 \\
\hline
\end{tabular}




\section{Results of the estimate}

With the normal two-crop system the production costs for the heated crop until 1 July amount to $f 24.75$ per $\mathrm{m}^{2}$ and for the autumn crop to $f 8.25$ per $\mathrm{m}^{2}$. Table 2 shows the estimated production costs for self-stoppers with the present growing techniques and for self-stoppers after mechanization of planting and harvesting. Table 2 shows that the profitability of year-round cropping with self-stopping tomatoes depends on the financial returns obtained for the first crop. If the financial returns of the present system amount to $f 22$ per $\mathrm{m}^{2}$ for the first crop and the yield of this crop is $8 \mathrm{~kg}$ per $\mathrm{m}^{2}$, the average price would be $f 2.75$ per $\mathrm{kg}$. It would seem that with increasing supplies reaching the markets in March, this price level would be the maximum, even without any self-stopping effects. In other words, the yield obtained on 15 March must be at least $8 \mathrm{~kg}$ per $\mathrm{m}^{2}$ at a price level of $f 2.75$ per $\mathrm{kg}$ if the costs are to be covered. With a supply of 20000 tons, the average price obtained for tomatoes in April was about $f 2.75$ per $\mathrm{kg}$ in recent years.

If it is assumed that the demand for tomatoes in March will be the same as it is in April, it would mean that in March 250 ha of self-stopping tomatoes could be harvested with an average production of 80 tonnes per hectare. This would of course also assume that only self-stopping crops are being grown.

\section{Direct costs in the summer months}

Table 3 contains an estimate of the direct costs in guilders per $\mathbf{m}^{2}$ (per $10 \mathrm{~kg}$ of tomatoes), again for two growing systems (Anon., 1973):

1. with the present techniques for planting, harvesting and crop clearance;

2. with mechanized planting, harvesting and crop clearance.

At an hourly labour rate of $f 15$ and a gas price of $f 0.12$ per $\mathrm{m}^{3}$, the direct costs per $\mathrm{kg}$ tomatoes would be respectively $f 0.67$ and $f 0.63$ at a yield of $10 \mathrm{~kg}$ per $\mathrm{m}^{2}$. In most years the average price of tomatoes during three or more successive weeks

Table 3. Direct costs in guilders per $\mathrm{m}^{2}$ for self-stopping tomatoes harvested in the period July to September.

\begin{tabular}{|c|c|c|}
\hline Factors & Present techniques & Mechanized techniques \\
\hline $\begin{array}{l}\text { Labour costs } \\
\quad \text { (see Table 1) }\end{array}$ & $10 / 60 \times f 12.40=f 2.07$ & $5.5 / 60 \times f 12.40=f 1.14$ \\
\hline $\begin{array}{l}\text { Machine costs: } \\
\text { for planting } \\
\text { for harvesting }\end{array}$ & & $\begin{array}{ll}f & 0.14 \\
f & 0.48\end{array}$ \\
\hline \multicolumn{3}{|l|}{ Plant material } \\
\hline Other materials and cultivation & f 0.20 & $f 0.20$ \\
\hline Energy, $6 \mathrm{~m}^{3}$ gas at $f 0.08$ & $f 0.48$ & $f 0.48$ \\
\hline Auction costs & $f 0.25$ & $f 0.25$ \\
\hline Total direct costs & $f 6.00$ & $f 5.69$ \\
\hline $\begin{array}{l}\text { Direct costs per } \mathrm{kg} \text { at a yield } \\
\text { of } 10 \mathrm{~kg} \text { per } \mathrm{m}^{2}\end{array}$ & $f 0.60$ & $f 0.57$ \\
\hline
\end{tabular}


in August has been below $f 0.50$ per $\mathrm{kg}$. The slack period starts usually in week 32 (second week in August).

If $f 0.60$ per $\mathrm{kg}$ tomatoes is regarded as the minimum price, average prices usually start to drop below this level in week 31, and this period lasts for five weeks or more. Cropping for the harvest period from the beginning of August until midSeptember is therefore economically justified only if the labour costs are much lower than those given in Table 3 . This may be achieved by using very cheap labour or by using permanent workers for whom no more productive work is available. If Dutch supplies are reduced in August and supplies from other sources remain the same, it could be that limited production for the August period might become economically justified again as average prices would tend to rise.

\section{The supply pattern}

If it is assumed that there are four crops of self-stopping tomatoes per year, then the harvest of the first crop should take place before 1 May, the harvest of the second crop before $15 \mathrm{July}$, of the third crop before 15 September and of the fourth crop before 30 November. On the basis of the present supply of tomatoes until the end of April (in 1974, 25000 tons, of which 2000 tons in March), it would be feasible to use 250 ha for year-round cropping. It would mean that the supply in November would increase from 4000 to 23000 tons and the remaining 2000 tons of the fourth crop would come in in October.

The supply until the end of April would also be much greater if self-stopping crops were to be introduced on a large scale into the present tomato acreage of 1200 ha (acreage on 1 February). Table 4 shows the monthly Dutch tomato supplies in 1973, the total imports of the UK, West Germany and France (average over the years 1969/73), as well as a prediction of the fortnightly supplies in the Netherlands if Dutch growers were to change over on a large scale to four selfstopping crops a year.

The supply until May would increase from 21000 tons in 1973 to 125000 tons, the first crop from 1250 hectares.

Table 4 shows that the harvest of the first crop would start on 15 February and that the harvest of the fourth crop would end at the end of November at the latest. Table 4 also shows that for the supply prediction used, it was assumed that four crops a year would be grown on $1050 \mathrm{ha}$, three crops on $100 \mathrm{ha}$, two crops on 150 ha and one crop on 400 ha.

For the two-crop system (150 ha), the first crop would be harvested in the second half of April and the second crop in July. This opens up the possibilities of combinations with autumn cucumbers, chrysanthemums, several lettuce crops and even freesias. However, the technical problems of cropping programmes which include self-stopping tomato crops will be left out of the discussion.

It was assumed that it would be technically possible to obtain a complete crop of $1 \mathrm{~kg}$ per plant or $10 \mathrm{~kg}$ per $\mathrm{m}^{2}$ in the second half of February. To achieve this there should be very few problems in fruit setting at the beginning of January. It must be stressed that year-round cropping with four crops of self-stopping tomatoes - from December until March, from March until May, from May until July and 
Table 4. Monthly Dutch tomato supplies, imports into the UK, West Germany and France and a prediction of Dutch tomato supplies from self-stopping crops with corresponding acreage to be harvested.

\begin{tabular}{|c|c|c|c|c|c|c|c|c|}
\hline \multirow[t]{2}{*}{ Period } & & \multirow{2}{*}{$\begin{array}{l}\text { Dutch } \\
\text { supplies }^{1}\end{array}$} & \multirow{2}{*}{$\begin{array}{l}\text { Imports } \\
\text { into } \\
\text { UK, } \\
\text { etc. }\end{array}$} & \multirow{2}{*}{$\begin{array}{l}\text { Pre- } \\
\text { dicted } \\
\text { supplies }\end{array}$} & \multicolumn{4}{|c|}{ Acreage in ha harvested } \\
\hline & & & & & $\begin{array}{l}3^{3} \text { st } \\
\text { crop }\end{array}$ & $\begin{array}{l}\text { 2nd } \\
\text { crop }\end{array}$ & $\begin{array}{l}3 \text { rd } \\
\text { crop }\end{array}$ & $\begin{array}{l}\text { 4th } \\
\text { crop }\end{array}$ \\
\hline January & & & 36 & & & & & \\
\hline February & 2 & & 31 & 20 & 200 & & & \\
\hline \multirow[t]{2}{*}{ March } & 1 & 1 & 44 & 20 & 200 & & & \\
\hline & 2 & & & 25 & 250 & & & \\
\hline \multirow{2}{*}{ April } & 1 & 19 & 54 & 30 & 300 & & & \\
\hline & 2 & & & 30 & 300 & & & \\
\hline \multirow{2}{*}{ May } & 1 & 66 & 106 & 35 & 150 & 200 & & \\
\hline & 2 & & & 35 & 150 & 200 & & \\
\hline \multirow[t]{2}{*}{ June } & 1 & 66 & 114 & 35 & 100 & 250 & & \\
\hline & 2 & & & 35 & 50 & 300 & & \\
\hline \multirow[t]{2}{*}{ July } & 1 & 70 & 85 & 35 & & 200 & 150 & \\
\hline & 2 & & & 35 & & 150 & 200 & \\
\hline \multirow[t]{2}{*}{ August } & 1 & 72 & 55 & 25 & & & 250 & \\
\hline & 2 & & & 30 & & & 300 & \\
\hline \multirow[t]{2}{*}{ September } & 1 & 33 & 36 & 20 & & & 200 & \\
\hline & 2 & & & 20 & & & 50 & 150 \\
\hline \multirow[t]{2}{*}{ October } & 1 & 20 & 40 & 20 & & & & 200 \\
\hline & 2 & & & 20 & & & & 200 \\
\hline \multirow[t]{2}{*}{ November } & 1 & 3 & 51 & 25 & & & & 250 \\
\hline & 2 & & & 25 & & & & 250 \\
\hline \multicolumn{2}{|l|}{ December } & & 40 & & & & & \\
\hline Total & & 350 & 693 & 520 & 1700 & 1300 & 1150 & 1050 \\
\hline
\end{tabular}

from August until November - is possible only on a large scale if there is practically a full first crop coming in from mid-February onwards.

Mention should also be made of the big changes in the supply after July which may be expected. The supply in August was assumed to be lower than the present supply because of the low prices and the relatively high direct costs of self-stoppers. The supply from September onwards becomes appreciably greater if the acreages mentioned are planted (see Table 4).

The changes in the supply before 1 May and after 1 September - as shown in Table 4 - are particularly great and from a marketing point of view they may become possible only by substitution, i.e. by replacing the outdoor tomatoes in the European market. 


\section{Conclusions and summary}

- The use of four self-stopping crops per year compared with the normal two-crop system is expected to give labour savings of $10 \%$ per unit area and about $50 \%$ per unit product.

- Important labour savings per unit area as well as per unit product are expected only if planting and harvesting can be mechanized. The savings are 51 and $72 \%$, respectively, compared with the present two-crop system, and 45 and $50 \%$, respectively, compared with self-stopping crops grown without mechanization.

- The estimated production costs for the first crop with harvest in March indicate that year-round cropping of self-stopping tomatoes on a large scale - say 1000 hectares (Table 4) - may be economically impossible. The prices which may be expected in the case of a supply of more than 100000 tons before May, would be well below the estimated production costs. The production costs estimated for the fourth crop, harvested in October, also appear to be higher than the prices which may be expected with a supply as mentioned in Table 4.

- Year-round cropping with four self-stopping crops looks economically attractive, provided the first harvest falls in March and makes at least $f 25$ per $\mathrm{m}^{2}$.

- The direct costs per $\mathrm{kg}$ tomatoes are too high at present to show a profit margin in August. Reduction of the supply in August could well bring an important improvement in the situation.

- It is possible that self-stopping tomatoes could be used successfully for an autumn crop. With a cropping cycle of $2 \frac{1}{2}$ months (Table 4 ) it would be possible to plant until the beginning of September.

- Year-round cropping on a large scale with four self-stopping crops would be technically feasible only if full crops can be guaranteed from mid-February until the end of November. It seems therefore that plant breeders and crop scientists have a lot of work to do to make it possible to meet these requirements.

\section{References}

Anonymous, 1973. Vademecum voor de Glastuinbouw. Landbouw-Economisch Instituut, Den Haag. 88 pp.

Anonymous, 1974a. Marktoverzicht tomaten. Markt- en Prijsbericht. P.G.F. Den Haag, No $4801.3 \mathrm{pp}$.

Anonymous, 1974b. Statistische Mededeling. P.G.F. Den Haag. No C 22-1974. 15 pp.

Buitelaar, K., 1973. Plantafstanden bij een kortdurende tomatenteelt in de herfst met een zelftoppend ras. Proefstation voor de Groenten- en Fruitteelt onder Glas, Naaldwijk, Intern jaarverslag 1973: 34-35.

Hogenboom, N. G., 1974. Een nieuwe toekomst voor de Nederlandse tomatenteelt. Groenten en Fruit 29 (31): 1407, 1409.

Postel, J. H. G., 1967. Teelt van lage tomaten. Proefresultaten in 1967. Pub. Inst. TuinbTech. Wageningen $26.7 \mathrm{pp}$.

Vriesenga, J. D. et al., 1972. High density tomato production. Am. Veg. Grower 20 (5): 34-36. 